\title{
A study on trace elements in fingernails and toenails from adult individuals by instrumental neutron activation analysis
}

\author{
Sanches $^{a}$ T. P., Genezini ${ }^{a}$, F. A., Saiki ${ }^{a}$ M. \\ aInstituto de Pesqusas Energéticas e Nucleares, IPEN-CNEN/SP, Centro do Reator de Pesquisas, CEP 05508-000, \\ Cidade Univesitária, São Paulo, SP, Brazil \\ mitiko@ipen.br
}

\begin{abstract}
This study presents results of instrumental neutron activation analysis (INAA) of nails from healthy adult individuals living in São Paulo city, Brazil. Concentrations of As, Br, Ca, Co, Cr, Fe, K, La, Na, Sb, Se and Zn were determined in fingernails and toenails and their variations with gender, age, body mass index among individuals and inter-element correlations were evaluated. These results indicated that several factors might affect in the nail element composition. In addition, there are few published data for finger and toenails analyses. However, comparisons made between the concentrations of elements obtained in fingernails were reasonable within the range of literature values. The findings of this study may contribute to establish an appropriate protocol to obtain data of nail element composition to be used as reference values.
\end{abstract}

Keywords: fingernails, toenails, neutron activation analysis, trace elements. 


\section{INTRODUCTION}

Analyses of human nails for their trace element contents have been studied for several decades to assess nutritional status, to estimate environmental or occupational exposure to contaminants and for clinical investigations [1-4]. However, until today, clinical laboratories and physicians have sought the reference ranges or control values of nail element concentrations to use nails in the assessment of exposure to toxic elements or of deficiencies of certain elements to human health.

The interest in the nail tissue analyses is due to its easy sampling, the collection is considered less invasive, more convenient for storage and less trouble to transport to the laboratory for the analyses and much less hazardous to handle. Unlike blood, saliva or urine samples, nails reflect the health events or exposures occurring over the past 6-10 months. They represent element contents in the human body over a long period of time [5, 6]. Moreover, human nails retain the highest concentrations of elements due to the content of keratin which incorporate trace elements in proportion to their dietary intakes and exposures. Nail tissues can contain information about metabolic events occurred during the time of their formation, that is, the elements are removed from metabolic processes and after nail formation may be stable markers of past exposure [7]. These attributes make nails an attractive tissue for evaluation of trace element concentrations and to use as biomarkers. Additionally, several studies have been conducted to prove that trace element concentrations in nails can be changed by several pathological, physiological, nutritional and environmental factors [8-16].

However, published data of nail analyses to be used as reference values are very limited. Besides, the wide variability of element concentrations in nails from a relatively homogeneous population has made it difficult to use this tissue as a biomarker for trace element status.

Within this context, the purpose of this study was to analyze fingernails and toenails of an adult group of individuals living in São Paulo city, Brazil, in order to examine factors that can affect its element composition.

In this study instrumental neutron activation analysis (INAA) was applied to analyze nail tissues. This method has been applied in the analyses of this tissue in several studies [12, 16-19]. INAA is known as a highly sensitive, precise and accurate analytical technique and very suitable for 
trace element determinations in biological tissues due to its multielement nature and small mass of sample required. In this case of human nails is particularly important since it is not always possible to obtain large sample amounts.

\section{MATERIALS AND METHODS}

\subsection{Nail sample collection}

The Ethics Committee of the Department of Public Health of the University of São Paulo approved this research. The nail sample donors were adult subjects considered healthy and living in São Paulo city, SP, Brazil. They were informed about the aim of the study and a written consent was obtained from each donor prior to sample collection. Those who agreed to take part in the study had to answer questions concerning residential and medical history, gender, age, eating and smoking habits, use of drugs, mineral supplement intakes and occupation. The answers of these questions were used to select the population group for this study. Subjects were excluded when they were pregnant and drug users, had mental diseases, apparent infections in their nails or hands or feet, when they did not have sufficient quantity of nails for analysis and patients with systemic or metabolic disorders.

Nail samples were collected from 27 individuals (12 males and 15 females) aged between 19 and 75 years (Mean $=38 \pm 16$ y) using stainless steel clippers. The donors themselves collected some samples. The fingernails and toenails collected separately were from 10 fingers and 10 toes. These samples were stored in small plastic zip bags securely closed, until their treatment for the analyses.

\subsection{Nail sample cleaning}

Nail sample cleaning was performed according to previous study [20]. To begin with, the samples were immersed in a solution of $70 \%$ ethanol for 10 min to avoid eventual contamination by infectious fungi and bacteria during the handling to obtain small sample fragments. The visible dirt on the surface of nails was removed manually. The nail clippings were then cut in small fragments using titanium coated scissors. These samples were placed in polyethylene vials and 
washed to minimize external surface contamination. This cleaning was performed in these vials and it consisted of three consecutive washings with acetone Merck pa stirring for 1 min, three consecutive washings with $2.0 \%$ TritonX100 solution also stirring for $1 \mathrm{~min}$, and finally two washes with Milli-Q purified water with a 20 s stirring each. Following washing, the samples were obtained by filtration on Whatman filter paper. Then the sample was dried at room temperature inside a laminar flow hood. During sample handling procedures talc-free gloves were used.

\subsection{Preparation of synthetic element standards}

The synthetic standards were prepared by pipetting $50 \mu \mathrm{L}$ of the element standard solutions onto sheets of Whatman No. 40 filter paper. These solutions containing one or more elements were prepared using certified standard solutions provided by SpexCertiprep Chemical, USA. All calibrations of the pipettors and volumetric flasks were verified before use. These filter sheets were dried at room temperature inside a desiccator and, then were placed into clean polyethylene bags which were then sealed. In these standards the quantities of each element, in $\mu \mathrm{g}$ (in parentheses) were the following: $\operatorname{As}(1.5), \operatorname{Br}(4.9), \operatorname{Ca}(500.6), \operatorname{Co}(0.150), \operatorname{Cr}(2.01), \operatorname{Fe}(360.3), \mathrm{K}(500.5)$, $\mathrm{La}(0.599), \mathrm{Na}(200.2), \mathrm{Sb}(0.600), \mathrm{Se}(8.003)$ and $\mathrm{Zn}(36.0)$.

\subsection{Instrumental neutron activation analysis procedure}

For each donor, about $170 \mathrm{mg}$ of fragmented and homogenized nail sample were weighted in polyethylene bags and irradiated in the IEA-R1 nuclear research reactor along with the synthetic standards of the elements. Sixteen-hour irradiations with a thermal neutron flux of about $4.5 \times 10^{12}$ $\mathrm{n} \mathrm{cm}^{-2} \mathrm{~s}^{-1}$ were performed for $\mathrm{As} \mathrm{Br}, \mathrm{Ca}, \mathrm{Co}, \mathrm{Cr}, \mathrm{Fe}, \mathrm{K}, \mathrm{La}, \mathrm{Na}, \mathrm{Sb}, \mathrm{Se}$ and $\mathrm{Zn}$ determinations. After adequate decay times, the activities of the irradiated samples and standards were measured by a Model GEM20190-P hyper pure Ge detector coupled to a gamma ray spectrometer, both from EG\&G ORTEC. The resolution (FWHM) of the system was $0.81 \mathrm{keV}$ for $122 \mathrm{keV}$ gamma-ray peak of ${ }^{57} \mathrm{Co}$ and $1.97 \mathrm{keV}$ for $1332 \mathrm{keV}$ gamma ray of ${ }^{60} \mathrm{Co}$. Each sample and standard were measured at least twice for different decay times. Counting times from 5,400 to 50,000 seconds were used, depending on the half-lives or activities of the radioisotopes considered. The gamma spectra were acquired using MAESTRO MCA software from EG\&G ORTEC and were processed using 
VISPECT software developed in our laboratory by Dennis Piccot from Saclay, France. The radionuclides measured were identified according to their half-lives and gamma-ray energies. The concentrations of elements were calculated by comparative method. The radionuclides used were: ${ }^{76} \mathrm{As},{ }^{82} \mathrm{Br},{ }^{47} \mathrm{Ca},{ }^{60} \mathrm{Co},{ }^{51} \mathrm{Cr},{ }^{59} \mathrm{Fe},{ }^{42} \mathrm{~K},{ }^{140} \mathrm{La},{ }^{24} \mathrm{Na},{ }^{122} \mathrm{Sb},{ }^{75} \mathrm{Se}$ and ${ }^{65} \mathrm{Zn}$.

The quality control of the analytical results was evaluated by analyzing certified reference materials, NIST 1577b Bovine Liver and NIST 1566b Oyster Tissue both from National Institute of Standards and Technology (NIST), USA.

\section{RESULTS AND DISCUSSION}

\subsection{Quality control of analytical results}

The certified reference materials, NIST 1577b Bovine Liver and NIST 1566b Oyster Tissue were analyzed by applying the same experimental conditions used for nail analyses and the results were evaluated on a dry weight basis, as recommended in their certificates. These results presented in Table 1 indicate good accuracy and precision with relative standard deviations and relative errors lower than $11.6 \%$. The standardized difference or Z-score values [23] obtained for elements quantified in these reference materials were $\mid \mathrm{Z}$-score $\mid<2$, indicating that the results are satisfactory and are within the ranges of certified data at the significance level of $5 \%$.

\subsection{Variation of element concentrations in fingernails and toenails}

Some of our experimental data presented outliers (values that are very different from the data values for the majority of the cases in the data set), so the normalized residual method [24] was used to obtain robust averages with minimum interference of outliers. Table 2 shows the results of mean \pm standard deviation and range of element concentrations obtained in fingernails and toenails.

Comparisons between fingernail and toenail element concentrations were carried out by applying one-way ANOVA test $(\mathrm{p}<0.05)$. In the lines of Table 2, results followed with same lower case letters indicate that this element concentration does not present significant difference between fingernails and toenails. Concentrations of $\mathrm{Br}, \mathrm{Co}, \mathrm{Fe}, \mathrm{Sb}, \mathrm{Se}$ and $\mathrm{Zn}$ obtained in fingernails were higher than those found in toenails. 
Table 1: Element concentrations in the NIST 1577b Bovine Liver and 1566b Oyster Tissue certified reference materials. Results in $\mathrm{mg} \mathrm{kg}^{-1}$

\begin{tabular}{|c|c|c|c|c|c|}
\hline \multirow{3}{*}{ Elements } & \multicolumn{5}{|c|}{ NIST 1577b Bovine Liver } \\
\hline & \multicolumn{4}{|c|}{ This study } & \multirow{2}{*}{ Certificate values [21] } \\
\hline & $M \pm S D(n)$ & RSD, \% & RE, \% & Z-score & \\
\hline $\mathrm{Br}$ & $10.10 \pm 0.33(7)$ & 3.3 & & & $(9.7)^{*}$ \\
\hline Co & $0.243 \pm 0.012(7)$ & 5.0 & & & $(0.25)^{*}$ \\
\hline $\mathrm{Fe}$ & $189 \pm 10(6)$ & 5.3 & 2.9 & 0.3 & $184 \pm 15$ \\
\hline $\mathrm{Na}$ & $2473 \pm 63(7)$ & 2.5 & 2.2 & 0.1 & $2420 \pm 60$ \\
\hline $\mathrm{Rb}$ & $13.07 \pm 0.41(6)$ & 3.1 & 4.5 & -0.5 & $13.7 \pm 1.1$ \\
\hline $\mathrm{Se}$ & $0.749 \pm 0.027$ & 3.6 & 2.7 & 0.3 & $0.73 \pm 0.06$ \\
\hline $\mathrm{Zn}$ & $123.9 \pm 3.1(6)$ & 2.5 & 2.4 & -0.2 & $127 \pm 16$ \\
\hline
\end{tabular}

NIST 1566b Oyster Tissue

\begin{tabular}{cccccc}
\cline { 2 - 4 } Elements & \multicolumn{3}{c}{ This study } & \multirow{2}{*}{ Certificate values [22] } \\
\cline { 2 - 4 } & $\mathrm{M} \pm \mathrm{SD}(\mathrm{n})$ & RSD, \% & RE, \% & Z-score & \\
\hline $\mathrm{As}$ & $7.35 \pm 0.34(6)$ & 4.6 & 3.9 & -0.9 & $7.65 \pm 0.65$ \\
$\mathrm{Br}$ & $52.8 \pm 1.7(7)$ & 3.2 & & & \\
$\mathrm{Ca}$ & $875 \pm 102(5)$ & 11.6 & 4.4 & 0.3 & $838 \pm 20$ \\
$\mathrm{Co}$ & $0.356 \pm 0.011(7)$ & 3.3 & 3.9 & 1.2 & $0.371 \pm 0.009$ \\
$\mathrm{Fe}$ & $196.6 \pm 7.6(5)$ & 3.9 & 4.4 & -0.9 & $205.8 \pm 6.8$ \\
$\mathrm{~K}$ & $6181 \pm 499(4)$ & 8.0 & 5.1 & -0.6 & $6520 \pm 90$ \\
$\mathrm{Na}$ & $3362 \pm 76(6)$ & 2.3 & 1.9 & 0.8 & $3297 \pm 53$ \\
$\mathrm{Rb}$ & $3.20 \pm 0.13(6)$ & 4.1 & 1.8 & -0.4 & $3.262 \pm 0.145$ \\
$\mathrm{Se}$ & $2.068 \pm 0.056(6)$ & 2.7 & 0.4 & 0.08 & $2.06 \pm 0.15$ \\
$\mathrm{Zn}$ & $1378 \pm 61(7)$ & 4.4 & 3.2 & -0.7 & $1424 \pm 46$
\end{tabular}

$\mathrm{M} \pm \mathrm{SD}=$ Arithmetic mean and standard deviation; $\mathrm{n}=$ Number of determinations;

$\mathrm{RSD}=$ Relative standard deviation; $\mathrm{RE}=$ Relative error; $*$ - Number in parentheses are informative values.

According to Gulson samples of toenails are superior to fingernails because of the reduced chance of contamination of toenails from various sources, including nails polish in the case of females, and due to the observation that toenails grow at a slower rate than fingernails and hence 
provide a longer integration of exposure [25]. Fingernails and toenails grow at different rates, this may affect concentration comparisons and exposure estimates. Fingernails of young adults grow at an average of $3.47 \mathrm{~mm} / \mathrm{month}$ and toenails grow $1.62 \mathrm{~mm} / \mathrm{month}[26]$.

In Table 2, the overall values, fingernail and toenail variability and interpersonal variability are also presented. The interpersonal variability was calculated as the mean of relative standard deviations (RSDs) representative of different individuals. These variations depended on the element. Elements $\mathrm{As}$ and $\mathrm{Cr}$ were distributed more homogeneously between fingernails and toenails than the other elements. The most heterogeneously distributed element was Co. Interpersonal variability results demonstrated the following sequence for the elements: $\mathrm{Co}>\mathrm{K}>\mathrm{La}$ $>\mathrm{Na}>\mathrm{Fe}>\mathrm{Sb}>\mathrm{Cr}>\mathrm{Br}>\mathrm{Ca}>\mathrm{As}>\mathrm{Se}>\mathrm{Zn}$.

Table 2: Mean element concentrations in the fingernails and toenails from all individuals. Results are given in mg. $\mathrm{kg}^{-1}$

\begin{tabular}{|c|c|c|c|c|c|}
\hline \multirow[t]{2}{*}{ Elements } & Fingernails & Toenails & \multirow{2}{*}{ Overall value } & \multirow{2}{*}{$\begin{array}{c}\text { Finger and } \\
\text { toenail } \\
\text { variability, } \\
\%\end{array}$} & \multirow[b]{2}{*}{$\begin{array}{c}\text { Interper } \\
\text { sonal } \\
\text { variabilit } \\
\text { y, \% }\end{array}$} \\
\hline & $\mathrm{M} \pm \mathrm{SD}$ & $\mathrm{M} \pm \mathrm{SD}$ & & & \\
\hline As & $0.044 \pm 0.013 \mathrm{a}$ & $0.047 \pm 0.015 \mathrm{a}$ & $0.046 \pm 0.002$ & 4.7 & 30.8 \\
\hline $\mathrm{Br}$ & $1.46 \pm 0.50 \mathrm{a}$ & $1.15 \pm 0.43 b$ & $1.31 \pm 0.22$ & 16.8 & 35.6 \\
\hline $\mathrm{Ca}$ & $647 \pm 225 a$ & $795 \pm 273 b$ & $721 \pm 104$ & 14.5 & 34.5 \\
\hline Co & $0.042 \pm 0.050 \mathrm{a}$ & $0.019 \pm 0.009 b$ & $0.031 \pm 0.016$ & 53.3 & 96.7 \\
\hline $\mathrm{Cr}$ & $0.243 \pm 0.094 \mathrm{a}$ & $0.240 \pm 0.140 \mathrm{a}$ & $0.242 \pm 0.002$ & 0.88 & 48.4 \\
\hline $\mathrm{Fe}$ & $29.0 \pm 15.3 \mathrm{a}$ & $19.6 \pm 9.7 b$ & $24.3 \pm 6.6$ & 27.3 & 51.4 \\
\hline K & $114 \pm 102 \mathrm{a}$ & $182.1 \pm 127.9 \mathrm{a}$ & $148.1 \pm 48.1$ & 32.5 & 77.6 \\
\hline $\mathrm{La}$ & $0.024 \pm 0.016 \mathrm{a}$ & $0.034 \pm 0.027 \mathrm{a}$ & $0.029 \pm 0.007$ & 24.4 & 74.1 \\
\hline $\mathrm{Na}$ & $143.6 \pm 90.1 \mathrm{a}$ & $230.7 \pm 155.0 \mathrm{a}$ & $187.2 \pm 61.6$ & 32.9 & 65.5 \\
\hline $\mathrm{Sb}$ & $0.040 \pm 0.017 \mathrm{a}$ & $0.025 \pm 0.015 b$ & $0.032 \pm 0.011$ & 32.5 & 49.2 \\
\hline $\mathrm{Se}$ & $0.540 \pm 0.210 \mathrm{a}$ & $0.402 \pm 0.053 b$ & $0.0471 \pm 0.098$ & 20.7 & 27.9 \\
\hline $\mathrm{Zn}$ & $114.2 \pm 20.2 \mathrm{a}$ & $87.4 \pm 11.9 b$ & $100.8 \pm 19.0$ & 18.8 & 15.9 \\
\hline
\end{tabular}

$\mathrm{M} \pm \mathrm{SD}=$ Arithmetic mean and standard deviation. Results with same lower-case letters of the same line indicate that they do not present statistically significant differences $(p<0.05,1$-way ANOVA). 


\subsection{Variations of element concentrations in relation to gender}

The $t$ Student test was applied to assess the effect of gender on mean element concentrations in fingernails and toenails. Results showed that most of the elements in toenails and fingernails are not affected by gender. The exceptions were for $\mathrm{Sb}, \mathrm{Se}$ and $\mathrm{Zn}$ of fingernails that showed significant differences $(p=0.05)$, as can be seen in Figure 1. These three elements showed higher concentrations in female fingernails than those presented in males. The mean concentrations and standard deviations obtained for these elements were (in mg. $\mathrm{kg}^{-1}$ ): $\mathrm{Sb}=0.046 \pm 0.019 ; \mathrm{Se}=0.62 \pm$ $0.24 ; \mathrm{Zn}=123 \pm 19$ for females and $\mathrm{Sb}=0.033 \pm 0.011 ; \mathrm{Se}=0.45 \pm 0.10 ; \mathrm{Zn}=104 \pm 17$ for males.

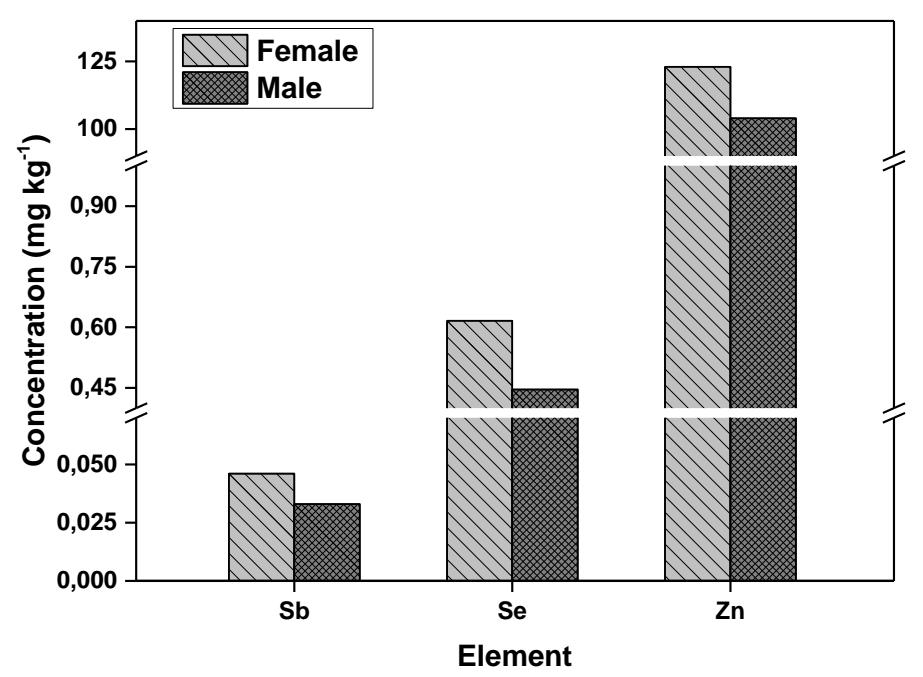

Figure 1: Concentrations of Sb, Se and $\mathrm{Zn}$ in female and male fingernails

\subsection{Variation of element concentrations in relation to age}

Age dependence with element concentrations in fingernails and toenails was not found for the 19 and 71 year range. A similar result was observed by Chaundhary et al. for $\mathrm{Br}, \mathrm{Co}, \mathrm{Cr}, \mathrm{Fe}, \mathrm{Na}$ and $\mathrm{Sb}$ in fingernails [27].

\subsection{Variations of element concentrations in relation to body mass index}

Body mass index (BMI) is an index of weight (mass, in $\mathrm{kg}$ ) to square height (in $\mathrm{m}^{2}$ ) ratio commonly used to classify underweight, suitable weight, overweight and obesity in adults. 
According to the Ministério da Saúde do Brasil [28] for BMI, 17 individuals presented adequate weight within the range from 18.5 to $25 \mathrm{~kg} \mathrm{~m}^{-2}$ and 10 were overweight with BMI from 25 to 30. Most of elements did not presented significant variation of element concentrations with the increasing of BMI. Only $\mathrm{Br}$ and Se concentrations from fingernails presented a slightly growth trend with BMI values as can be seen in Figure 2.

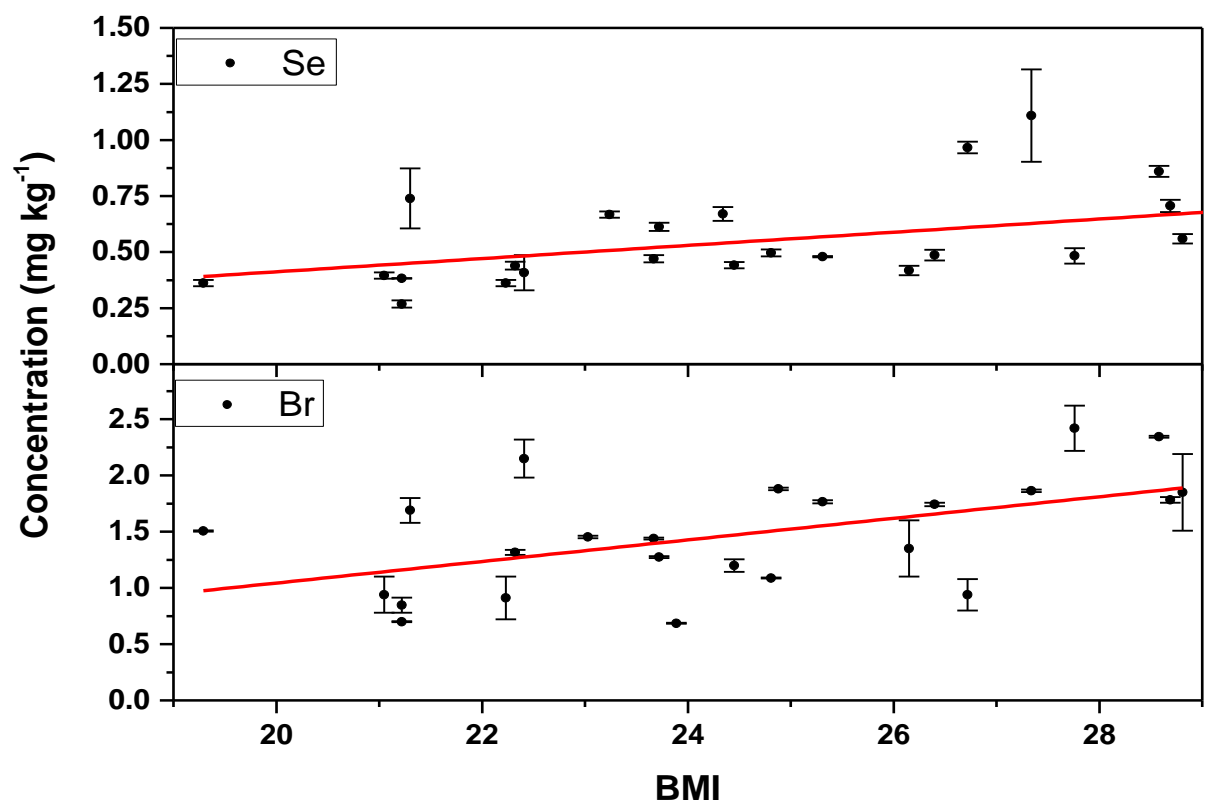

Figure 2: Variation of the fingernail Br and Se concentrations with de body mass index (BMI)

\subsection{Inter-element correlation}

To evaluate potential inter-element correlation, Pearson correlation coefficients were calculated, and these results are presented in Table 3. For fingernails, very strong positive correlation (r) was obtained for the pair of elements $\mathrm{K}-\mathrm{Na}(0.90)$ and moderate positive correlations for $\mathrm{Cr}-\mathrm{Co}(\mathrm{r}=$ $0.55), \mathrm{Cr}-\mathrm{Fe}(\mathrm{r}=0.51)$, and $\mathrm{Se}-\mathrm{Zn}(\mathrm{r}=0.53)$. In the case of toenails, significant strong correlations were obtained for $\mathrm{Cr}-\mathrm{Fe}(0.70), \mathrm{K}-\mathrm{Na}(0.64)$ and $\mathrm{La}-\mathrm{Cr}(0.61)$ and $\mathrm{La}-\mathrm{Zn}(0.69)$ and moderate correlations for $\mathrm{Fe}-\mathrm{Se}(0.59), \mathrm{La}-\mathrm{Co}(0.50), \mathrm{La}-\mathrm{Fe}$ (0.50). Positive correlations between $\mathrm{K}$ and $\mathrm{Na}$ found in fingernails and toenails can be related to these two electrolytes responsible to maintain 
homeostasis within the body. Sodium influences many of the same bodily functions as potassium and this correlation was also verified by some authors [27, 29-31]. The positive correlations found in this study for Se-Zn and for Cr-Fe in fingernails were also obtained by Chaudhary et al. [27] and Carneiro et al. [32]. Correlations of $\mathrm{Cr}-\mathrm{Co}$ and of $\mathrm{Se}-\mathrm{Zn}$ were found only in fingernails. On the other hand, the positive correlations of Fe-Se, La-Co, La-Cr, La-Fe and $\mathrm{La}-\mathrm{Zn}$ were obtained only in toenails. These findings are of interest because there are no reports of possible differences in the interrelationships of these elements in fingernails and toenails.

Table 3: Positive strong correlation coefficients for fingernail and toenail elements (Only significant Pearson correlation coefficients $r$ for $p<0.05$ are presented)

\begin{tabular}{cccc}
\hline \multicolumn{1}{c}{ Fingernails } & \multicolumn{2}{c}{ Toenails } \\
\hline Inter-elements & $\mathbf{r}$ & Inter-elements & $\mathbf{r}$ \\
\hline $\mathrm{Co}-\mathrm{Cr}$ & 0.55 & $\mathrm{La}-\mathrm{Co}$ & 0.50 \\
$\mathrm{Cr}-\mathrm{Fe}$ & 0.51 & $\mathrm{Cr}-\mathrm{Fe}$ & 0.70 \\
$\mathrm{~K}-\mathrm{Na}$ & 0.90 & $\mathrm{La}-\mathrm{Cr}$ & 0.61 \\
$\mathrm{Se}-\mathrm{Zn}$ & 0.53 & $\mathrm{La}-\mathrm{Fe}$ & 0.50 \\
& & $\mathrm{~K}-\mathrm{Na}$ & 0.64 \\
& & $\mathrm{La}-\mathrm{Zn}$ & 0.69 \\
& & $\mathrm{Fe}-\mathrm{Se}$ & 0.59 \\
\hline
\end{tabular}

\subsection{Concentration ranges of elements in fingernails and toenails}

Although the element concentrations in nails vary due to geographical differences, nutritional status and environmental factors, the results obtained were compared with some reported values for healthy adult groups. Most of fingernails results (Table 4) are reasonably within the range of literature values presented in Table 5. For As, the result obtained is lower than that published value [33] and also for Cr result was lower than those reported for this element [27, 34, 35].

Results obtained in this study for toenails are presented in Table 6. There are few reported data (Table 7) in order to make any comparison with the results of this study. The toenail Se and $\mathrm{Zn}$ concentrations obtained are within the reported values. However, for As, the result obtained is again lower. Furthermore, the results obtained for $\mathrm{Co}, \mathrm{Cr}$ and $\mathrm{Fe}$ are lower than those presented by Menezes et al. [39]. In the absence of reported data for the toenail $\mathrm{K}, \mathrm{La}$ and $\mathrm{Sb}$ comparisons were not possible. 
Table 4: Element concentrations in fingernails from adult individuals living in São Paulo city

\begin{tabular}{ccccc}
\hline \multirow{2}{*}{ Elements } & \multicolumn{3}{c}{ Element concentrations (in mg.kg-1) obtained for fingernails in this study } \\
\cline { 2 - 5 } & $\mathbf{M} \pm \mathbf{S D}(\mathbf{n})$ & $\mathbf{M}_{\mathbf{G}} \times / \div \mathbf{S D}_{\mathbf{G}}$ & Range & Median \\
\hline $\mathrm{As}$ & $0.044 \pm 0.013(23)$ & $0.042 \times / \div 1.36$ & $0.036-0.064$ & 0.0415 \\
$\mathrm{Br}$ & $1.46 \pm 0.50(25)$ & $1.37 \times / \div 1.44$ & $0.70-2.42$ & 1.45 \\
$\mathrm{Ca}$ & $647 \pm 225(26)$ & $600 \times / \div 1.54$ & $161-1045$ & 682 \\
$\mathrm{Co}$ & $0.042 \pm 0.050(26)$ & $0.031 \times / \div 1.94$ & $0.016-0.25$ & 0.0254 \\
$\mathrm{Cr}$ & $0.243 \pm 0.094(25)$ & $0.225 \times / \div 1.49$ & $0.11-0.46$ & 0.255 \\
$\mathrm{Fe}$ & $29.0 \pm 15.3(25)$ & $25.7 \times / \div 1.64$ & $10-66$ & 23.6 \\
$\mathrm{~K}$ & $102.1 \pm 88.4(18)$ & $64.5 \times / \div 3.13$ & $5.46-291.0$ & 74.7 \\
$\mathrm{La}$ & $0.024 \pm 0.016(23)$ & $0.0148 \times / \div 4.37$ & $0.00015-0.060$ & 0.207 \\
$\mathrm{Na}$ & $143.6 \pm 90.1(26)$ & $108.2 \times / \div 2.49$ & $9.4-324.0$ & 142.4 \\
$\mathrm{Sb}$ & $0.040 \pm 0.017(23)$ & $0.037 \times / \div 1.46$ & $0.019-0.086$ & 0.0331 \\
$\mathrm{Se}$ & $0.541 \pm 0.206(25)$ & $0.509 \times / \div 1.41$ & $0.27-1.11$ & 0.479 \\
$\mathrm{Zn}$ & $114.2 \pm 20.2(26)$ & $112.4 \times / \div 1.20$ & $72-148$ & 113.8 \\
\hline
\end{tabular}

$\mathrm{M} \pm \mathrm{SD}=$ Arithmetic mean and standard deviation; $\mathrm{n}=$ number of individuals; $\mathrm{M}_{\mathrm{G}} \times / \div \mathrm{SD}_{\mathrm{G}}=$ Geometric mean and standard deviation

Table 5: Reported values of element concentrations in fingernails from adult individuals

\begin{tabular}{cccccc}
\hline \multirow{2}{*}{ Elements } & \multicolumn{5}{c}{ Reported values (in mg.kg-1) for fingernails } \\
\cline { 2 - 6 } & $\mathbf{M} \pm \mathbf{S D}[34]$ & $\mathbf{M}_{\mathbf{G}} \times / \div \mathbf{S D}_{\mathbf{G}}[\mathbf{3 5}]$ & $\mathbf{M} \pm \mathbf{S D}[33]$ & $\mathbf{M}[\mathbf{2 7}]$ & $\mathbf{M} \pm \mathbf{S D}[\mathbf{1 6}]$ \\
\hline $\mathrm{As}$ & $0.029 \pm 0.190$ & $0.0307 \times / \div 1.16$ & $0.61 \pm 0.21$ & 0.0545 & $0.40 \pm 0.13$ \\
$\mathrm{Br}$ & $23 \pm 14$ & $2.10 \times / \div 1.05$ & $1.65 \pm 0.71$ & 2.11 & $0.92 \pm 0.39$ \\
$\mathrm{Ca}$ & $670 \pm 240$ & $522 \times / \div 1.06$ & $926 \pm 383$ & 665 & \\
$\mathrm{Co}$ & $0.035 \pm 0.031$ & $0.0275 \times / \div 1.10$ & & 0.0421 & $0.12 \pm 0.07$ \\
$\mathrm{Cr}$ & $1.16 \pm 1.05$ & $1.760 \times / \div 1.10$ & & 0.898 & $0.62 \pm 0.28$ \\
$\mathrm{Fe}$ & $42 \pm 30$ & $13.5 \times / \div 1.08$ & $77.8 \pm 67.2$ & 19.5 & $68.56 \pm 23.40$ \\
$\mathrm{~K}$ & $210 \pm 260$ & $45.8 \times / \div 1.16$ & $91.1 \pm 41.0$ & 94.6 & \\
$\mathrm{La}$ & $0.120 \pm 0.180$ & & & & \\
$\mathrm{Na}$ & $240 \pm 240$ & $133 \times / \div 1.07$ & & 157 & \\
$\mathrm{Sb}$ & $0.053 \pm 0.054$ & $0.0243 \times / \div 1.10$ & & 0.0366 & $0.068 \pm 0.032$ \\
$\mathrm{Se}$ & $0.940 \pm 0.210$ & $1.06 \times / \div 1.03$ & $1.28 \pm 0.34$ & 1.003 & $0.80 \pm 0.40$ \\
$\mathrm{Zn}$ & $120 \pm 29$ & $149 \times / \div 3.3$ & $113 \pm 20$ & 147 & $103.24 \pm 38.96$ \\
\hline
\end{tabular}

$\mathrm{M} \pm \mathrm{SD}=$ Arithmetic mean and standard deviation; $\mathrm{MG} \times / \div \mathrm{SD}_{\mathrm{G}}=$ Geometric mean and standard deviation; $\mathrm{M}=$ Arithmetic mean 
Table 6: Element concentrations in toenails from adult individuals living in São Paulo city

\begin{tabular}{ccccc}
\hline \multirow{2}{*}{ Elements } & \multicolumn{3}{c}{ Element concentrations $($ in $\mathbf{~ m g . k g - 1}$ ) obtained for toenails in this study } \\
\cline { 2 - 5 } & $\mathbf{M} \pm \mathbf{S D}(\mathbf{n})$ & $\mathbf{M}_{\mathbf{G}} \times / \div \mathbf{S D}_{\mathbf{G}}$ & Range & Median \\
\hline $\mathrm{As}$ & $0.047 \pm 0.015(24)$ & $0.045 \times / \div 1.41$ & $0.022-0.072$ & 0.0456 \\
$\mathrm{Br}$ & $1.15 \pm 0.43(25)$ & $1.077 \times / \div 1.47$ & $0.49-2.00$ & 1.046 \\
$\mathrm{Ca}$ & $795 \pm 273(26)$ & $743 \times / \div 1.47$ & $254-1363$ & 794 \\
$\mathrm{Co}$ & $0.019 \pm 0.009(25)$ & $0.0176 \times / \div 1.58$ & $0.0098-0.416$ & 0.0168 \\
$\mathrm{Cr}$ & $0.239 \pm 0.142(24)$ & $0.191 \times / \div 2.09$ & $0.035-0.48$ & 0.230 \\
$\mathrm{Fe}$ & $19.6 \pm 9.7(21)$ & $17.6 \times / \div 1.61$ & $7.2-43.0$ & 18.6 \\
$\mathrm{~K}$ & $182.1 \pm 127.9(23)$ & $129.3 \times / \div 2.84$ & $4.8-506.0$ & 152.0 \\
$\mathrm{La}$ & $0.034 \pm 0.027(21)$ & $0.0241 \times / \div 2.46$ & $0.0027-0.1064$ & 0.0274 \\
$\mathrm{Na}$ & $230.7 \pm 155.0(25)$ & $177.0 \times / \div 2.27$ & $25.9-585.0$ & 191.0 \\
$\mathrm{Sb}$ & $0.025 \pm 0.015(23)$ & $0.021 \times / \div 1.73$ & $0.0094-0.057$ & 0.084 \\
$\mathrm{Se}$ & $0.402 \pm 0.053(22)$ & $0.417 \times / \div 1.13$ & $0.32-0.54$ & 0.411 \\
$\mathrm{Zn}$ & $87.4 \pm 11.9(23)$ & $86.6 \times / \div 1.14$ & $63.8-111.0$ & 88.6
\end{tabular}

$\mathrm{M} \pm \mathrm{SD}=$ Arithmetic mean and standard deviation; $\mathrm{n}=$ number of individuals; $\mathrm{M}_{\mathrm{G}} \times / \div \mathrm{SD}_{\mathrm{G}}=$ Geometric mean and standard deviation

Table 7: Reported values of element concentrations in toenails from adult individuals

\begin{tabular}{|c|c|c|c|c|}
\hline \multirow{2}{*}{ Elements } & \multicolumn{4}{|c|}{ Reported values (in mg.kg-1) for toenails } \\
\hline & $\mathrm{M} \pm \mathrm{SD}[36]$ & $\mathrm{M} \pm \mathrm{SD}[37]$ & $\mathrm{M} \pm \mathrm{SD}[2]$ & Range [38] \\
\hline As & & $0.12 \pm 0.13$ & $0.12 \pm 0.27$ & \\
\hline $\mathrm{Br}$ & & $0.96 \pm 3.56$ & $2.41 \pm 1.22$ & \\
\hline $\mathrm{Ca}$ & & $714 \pm 303$ & $968 \pm 4361$ & \\
\hline Co & $0.02 \pm 0.04$ & $0.037 \pm 0.032$ & $0.042 \pm 0.023$ & $0.2-0.3$ \\
\hline $\mathrm{Cr}$ & $0.58 \pm 0.5$ & $0.97 \pm 0.91$ & $2.39 \pm 2.91$ & $1.6-4$ \\
\hline $\mathrm{Fe}$ & & $25.2 \pm 20.4$ & $42.5 \pm 26.3$ & $78-323$ \\
\hline $\mathrm{Na}$ & & $25.2 \pm 40.2$ & & \\
\hline $\mathrm{Se}$ & $0.52 \pm 0.10$ & $0.83 \pm 0.23$ & $0.92 \pm 0.15$ & \\
\hline $\mathrm{Zn}$ & $70.1 \pm 18.5$ & $111 \pm 29.9$ & $110 \pm 28.9$ & $57-290$ \\
\hline
\end{tabular}

$\mathrm{M} \pm \mathrm{SD}=$ Arithmetic mean and standard deviation 


\section{CONCLUSIONS}

From the results obtained, it can be concluded that there were differences between mean element concentrations of fingernails and toenails depending on the element. The mean concentrations of some elements varied with gender and body mass index but not with age of the adult individuals aged 19-71 years. In addition, Pearson correlation coefficients revealed significant strong associations between $\mathrm{K}-\mathrm{Na}$ (for fingernails) and $\mathrm{Cr}-\mathrm{Fe}$ and $\mathrm{La}-\mathrm{Zn}$ in toenails. The determinations of these correlations can be useful to help understand how the elements enter the body and the mechanisms of its actions.

The knowledge of the factors that affects in the nail element composition can contribute to obtain reliable ranges of concentrations in nails to be used as reference values.

A comparison between nail results obtained in this study with reported values was not so easy since there are few published data for a control population, distinct procedures used for cleaning the nails and the population differences that are influenced by environmental, geographical and nutritional factors. However, most of data obtained are within the range of reported values.

Concerning the methodology, results of analytical quality control demonstrated the viability of using the procedure of INAA adopted in this study to obtain reliable fingernail and toenail element concentrations.

\section{ACKNOWLEDGMENT}

Authors thank the São Paulo Research Foundation (FAPESP) and the Brazilian National Council for Scientific and Technological Development (CNPq), from Brazil for financial support. The author T. P. Sanches is grateful for a fellowship from the Brazilian Nuclear Energy Commission

\section{REFERENCES}


[1] OYOO-OKOTH, E.; ADMIRAAL, W.; OSANO, O.; KRAAK, M. H. S. Element profiles in hair and nails of children reflect the uptake from food and the environment. Environ Toxicol Chem, v. 31, p. 1461-1469, 2012.

[2] GARLAND, M.; MORRIS, J. S.; ROSNER, B. A.; STAMPFER, M. J.; SPATE, V. L.; BASKETT, C. J.; WILLETT, W. C.; HUNTER, D. J. Toenail trace element levels as biomarkers: reproducibility over a 6-year period. Cancer Epidemiol Biomarkers Prev, v. 2, p. 493-497, 1993.

[3] HE, K. Trace elements in nails as biomarker in clinical research. Eur J Clin Invest, v. 41, p. 98-102, 2011.

[4] TRUC PHUONG, H.; PHAM NGOC TRINH, T.; THANH BINH, D.; THI TRUC LINH, N.; THI HONG LOAN, T.; TUAN ANH, T.; MANH DUNG, H.; VAN DONG N. Determination of the concentration of $\mathrm{Fe}, \mathrm{Se}$, and $\mathrm{Zn}$ elements in nails of Vietnamese women with breast cancer using k0-INAA method. Sci Tech Dev J, v. 22, p.370-377, 2019.

[5] DANIEL, C.R.; PIRACCINI, B.M.; TOSTI, A. The nail and hair in forensic science. J Am Acad Dermatol, v. 50, p. 258-261, 2004.

[6] PALMERI, A.; PICHINI, S.; PACIFICI, R.; ZUCCARO, P.; LOPEZ, A. Drugs in nails. Clin Pharmacokinet, v. 38, p. 95-110, 2000.

[7] HOPPS, H. C. The biologic bases for using hair and nail analyses of trace elements. Sci Total Environ, v. 7, p. 71-89, 1977.

[8] ILYAS, A.; AHMAD, H.; SHAH, M. H. Comparative study of elemental concentrations in the scalp hair and nails of myocardial infarction patients versus controls from Pakistan. Biol Trace Elem Res, v.166, p. 123-135, 2015.

[9] MOMEN, A. B.; KHALID, M. A. A.; ELSHEIKLH, M. A. A.; ALI, D. M. H. Trace elements in scalp hair and fingernails as biomarkers in clinical studies. J Health Spec, v. 3, p.28-34, 2015.

[10] MORESCO, M. B.; FLEEK, A. S.; CARNEIRO, M. F. H.; BARBOSA JUNIOR, F.; AMANTEA, S. L.; RHODEN, C. R. Trace elements concentration in nail and association with airway inflammation in adolescents. Biol Trace Elem Res, v. 161, p. 161-166, 2014. 
[11] GHAZAli, A. R.; KAMARUlZAMAN, F.; NORMH, C. D.; AHMD, M.; GHAZALI, S. E.; IBRAHIM, N.; SAID, Z.; SHAHAR, S.; ANGKAT, N.; RAZALI, R. Levels of metallic elements and their potential relationships to cognitive function among elderly from federal Land Development Authority (FELDA) settlement in Selangor Malaysia. Biol Trace Elem Res, v. 153, p. 16-21, 2013.

[12] BROCKMANN, J.D.; GUTHRIE, J. M.; MORRIS, J. S.; DAVIS, J.; MADSEN, R.; ROBERTSON, J. D. Analysis of the toenail as a biomonitor of supranutritional intake of $\mathrm{Zn}, \mathrm{Cu}$ and Mg. J Radioanal Nucl Chem, v. 279, p. 405-410, 2009.

[13] NORWAK, B.; CHMIELNICKA, J. Relationship of lead and cadmium to essential elements in hair, teeth, and nails of environmentally exposed people. Ecotoxicol Environ Safe, v. 46 p. 265-274, 2000

[14] KUCERA, J.; BENCKO, V.; TEJRAL J.; BORSKÁ, L.; SOUKAL, L.; RANDA Z. Biomonitoring of occupational exposure: Neutron activation determination of selected metals in the body tissues and fluids of workers manufacturing stainless steel vessels. J Radioanal Nucl Chem, v. 259, p. 7-11, 2004.

[15] SAVINOVA, S. S.; SHARYPOVAA, R. M.; DROBYSHEVA, A. I. Determination of the trace element composition of human nails. J Anal Chem, v.75, p.409-415, 2020.

[16] HUYNH, P.; DINH, B. ; TRAN, A.; HO, D. Analysis of trace elements in the fingernails of breast cancer patients using instrumental neutron activation analysis. J Radioanal Nucl Chem, v. 324, p. 663-671, 2020.

[17] MORRIS, J.S.; SPATE, V. L.; NGWENYAMA, R. A.; WALTERS, D. J. Determination of selenium status using the nail biologic monitor in a canine model. J Radioanal Nucl Chem, v. 291, p. 439-444, 2012.

[18] KARAGAS, M. R.; TOSTESON, T. D.; BLUM, J.; KLAUE, B.; WEISS, J. E.; STANNARD, V.; SPATE, V.; MORRIS, S. Measurement of low levels of arsenic exposure: a comparison of water and toenail concentrations. Am J Epidemol, v. 152, p. 84-90, 2000. 
[19] ZUKOWSKA, J.; BODE, P.; BIZIUK, M. Toenail selenium level among healthy residents of two Polish Districts. J Radioanal Nucl Chem, v. 280, p. 621-627, 2009.

[20] SANCHES, T.P.; SAIKI, M. Establishing a protocol for element determinations in human nail clippings by neutron activation analysis. In: INTERNATIONAL NUCLEAR ATLANTIC CONFERENCE, INAC 2011, Belo Horizonte. Annals ..., Comissão Nacional de Energia Nuclear, 2011. Available at: https://www.ipen.br/biblioteca/2011/inac/17078.pdf . Last acessed: 27 jun 2020.

[21] NIST - National Institute of Standards and Technology. Standard reference material 1577b Bovine Liver, 1991, 4p.

[22] NIST - National Institute of Standards and Technology. Standard reference material 1566b Oyster Tissue, 2001, 8p.

[23] KONIECZKA, P.; NAMIESNIK, J. Quality assurance and analytical control in the Analytical laboratory: a practical approach, New York: CRC Press, 2009.

[24] JAMES, M.F.; MILLST, R. W.; WEAVER, D. R. The use of the normalized residual in averaging experimental data and in treating outliers. Nucl Instrum Meth, v. 313, p. 277-282, 1992.

[25] GULSON, B. L. Nails: concern over their use in lead exposure assessment. Sci Total Environ, v. 177, p. 323-327, 1996.

[26] YAEMSIRI, S.; HOU, N.; SLINING, M. M.; HE, K. Growth rate of human fingernails and toenails in healthy American young adults. J Eur Acad Dermatol Venereol, v. 24, p. 420-423, 2010.

[27] CHAUDRARY, K.; EHAMANN, W. D.; RENGAN, K.; MASESBERY, W. R. Trace element correlation with age and sex in human fingernails. J Radioanal Nucl Chem, v. 195, p. $51-56,1955$.

[28] BRASIL - Ministério da Saúde. IMC em adultos, 2017. Available at: http://www.saude.gov.br/component/content/article/804-imc/40509-imc-em-adultos. Last acessed: 20 Jan. 2020. 
[29] NOWAK, B. Occurrence of heavy metals, sodium, calcium, and potassium in human hair, teeth, and nails. Biol Trace Elem Res, v. 52, p. 11-22, 1996.

[30] HOSSEINIMAKAREM, Z.; TAVASSOLI, S. H. Analysis of human nails by laser-induced breakdown spectroscopy. J Biom Opt, v. 16, p. 057002-1-057002-8, 2011.

[31] BAHREINI, M.; HOSSEINIMAKAREM, Z.; TAVASSOLI, S. H. A study of association between fingernail elements and osteoporosis by laser-induced breakdown spectroscopy, J Appl Phys, v. 112, p. 054701- 1-054701-9, 2012.

[32] CARNEIRO, M. F. H.; RODEN, C. R.; AMANTÉA, S. L.; BARBOSA-JUNIOR, F. Low concentrations of selenium and zinc in nails are associated with childhood asthma. Biol Trace Elem Res, v. 144, p. 244-252, 2011.

[33] BISWAS, S. K.; ABDULlAH, M.; AKHTER, S.; TARAFDAR, S. A.; KHALIQUZZAMAN, M.; KHAN, A. H. Trace element in human fingernails measurement by proton-induced X-ray emission. J Radional Nucl Chem, v. 82, p. 111-124, 1984.

[34] RODUSHKIN, I.; AXELSSON, M. Application of double focusing sector field ICP-MS for multielemental characterization of human hair and nails, Part II. A study of the inhabitants of northern Sweden. Sci Total Environ, v. 262, p. 21-36, 2000.

[35] VANCE, D. E.; EHMANN, W. D.; MARKESBERY, W. R. Trace element content in fingernails and hair of a nonindustrialized US control population. Biol Trace Elem Res, v. 17, p. 109-121, 1988.

[36] O’RORKE, M.; CANTWELL, M. M.; ABNET, C. C.; BROCKMAN, J. D.; MURRAY, L. J. Toenail trace element status and risk of Barrett's study oesophagus and oesophageal adenocarcinoma: Results from the FINBAR study. Int J Cancer, v. 131, p. 1882-1891, 2012.

[37] CHENG, T. P.; MORRIS, J. S; KOIRTYOHANN, S. R.; SPATE, V. L.; BASKETT, C. K. The analysis of human nails for 24 elements via $K_{o}$ and cyclic neutron activation analysis. Nucl Instr Meth Phys Res A, v. 353, p. 457-460, 1994. 
[38] MENEzeS, M. Â. B. C.; MAIA, E. C. P.; Albinati, C. C. B.; SABINO, C. V. S.; BATISTA, J. R. How suitable are scalp hair and toenail as biomonitor? J Radioanal Nucl Chem, v. 259, p. 81-86, 2004. 